\title{
EXPLORING THE CONCEPT OF KOTA KINABALU CITY AS AN URBAN ECOTOURISM DESTINATION
}

\author{
Nattana Simon ${ }^{1}$, Fiffy Hanisdah Saikim² \& Awangku Hassanal Bahar Pengiran Bagul ${ }^{3}$ \\ ${ }^{1,2}$ Institute for Tropical Biology and Conservation, Universiti Malaysia Sabah, Malaysia, \\ ${ }^{3}$ Faculty of Business, Economics and Accountancy, Universiti Malaysia Sabah, Malaysia \\ (natanas@gmail.com, fiffy@ums.edu.my, hbagul@ums.edu.my)
}

\begin{abstract}
The concept of ecotourism which applies to tourism activities in natural and undisturbed environments, is frequently thought to be antonymous with urban environments, however, can be proven possible. Despite Sabah being well regarded for its ecotourism sector, the concept of urban ecotourism in the city of Kota Kinabalu has yet to be explored. Existing ecotourism destinations in Sabah are facing carrying capacity problems thus there is a growing need to explore new and different destinations or attractions to meet the demand of tourists. This study examined local Kota Kinabalu residents and tourists' perception and values pertaining to the potential of Kota Kinabalu as an urban ecotourism destination as well as how preservation of green spaces in cities encouraged sustainability using a multi-methodological approach. Based on the results of this study, both respondent groups ranked Kota Kinabalu city as having a high potential as an urban ecotourism destination. In addition, the results of this study could assist decision or policymakers in the local tourism sector with tourism development decisions.
\end{abstract}

KEYWORDS: Urban Ecotourism, Green Space Conservation, Sustainable Tourism, Tourism Development, Destination Competitiveness

\section{PURPOSE AND BACKGROUND}

The concept of ecotourism which applies to tourism activities in natural and undisturbed environments, has always been thought to be antonymous with urban environments, however, the reverse can be proven possible. Despite Sabah being well regarded for its ecotourism sector, the concept of urban ecotourism in the city of Kota Kinabalu has yet to be explored. Existing ecotourism destinations in Sabah are facing carrying capacity problems thus there is a growing need to explore new and different destinations or attractions to meet the demand of tourists.

\section{METHODOLOGY}

This study examined local Kota Kinabalu residents and tourists' perception and value pertaining to the potential of Kota Kinabalu as an urban ecotourism destination as well as how preservation of green spaces in cities encourages sustainability by using a multi-methodological approach.

\section{FINDINGS}

Based on the results of this study, both respondent groups rank Kota Kinabalu city as having a high potential as an urban ecotourism destination. 


\section{CONCLUSION}

The ultimate goal is to ensure that the natural environment and its resources are be protected regardless of whether it is an urban or rural area, although not gazetted as a recreation or tourism area and whether or not it is in pristine condition.

\section{CONTRIBUTION/PRACTICAL IMPLICATIONS}

In addition, the results of this study could assist decision or policymakers in the local tourism sector to plan and execute tourism development programmes.

\section{REFERENCES}

Aronson, M. F. J., Lepczyk, C. A., Evans, K. L., Mark A Goddard, M. A., Lerman, S. B., Maclvor, J. S., Nilon, C. H., \& Vargo, T. (2017). Biodiversity in the city: Key challenges for urban green space management. Frontiers in Ecology and Environment, 15(4), 189-196.

Boley, B. B., \& Green, G. T. (2015). Ecotourism and natural resource conservation: The potential for a sustainable symbiotic relationship. Journal of Ecotourism, 15(1), 36-50.

Dearborn, D. C., \& Salit, K. (2009). Motivations for conserving urban biodiversity. Conservation Biology, 24(2), 432-440. 